\title{
Karakteristik penderita kanker serviks di RSUP Prof. Dr. R. D. Kandou Manado periode 1 Januari 2013 - 31 Desember 2015
}

\author{
${ }^{1}$ Andre M. Watulingas \\ ${ }^{2}$ Maria Loho \\ ${ }^{2}$ Freddy Wagey
}

\author{
${ }^{1}$ Kandidat Skripsi Fakultas Kedokteran Universitas Sam Ratulangi Manado \\ ${ }^{2}$ Bagian Obstetri dan Ginekologi Fakultas Kedokteran Universitas Sam Ratulangi \\ Email: watulingas.andre@yahoo.com
}

\begin{abstract}
Cervical cancer and breasts cancer are both a cancer disease with the highest presentation in Indonesian in the time of 2013, that is $0,8 \%$ for cervical cancer and $0,5 \%$ for breasts cancer. In general this disease are managed $70-75 \%$ already on the advanced stadium with high mortality rate. Untill now cervical cancer are the reason of the highest death cases cause by cancer in the developing country. This study aimed to obtain the characteristics of patients with cervical cancer in the Department of Obstetric and Gynaecology in the Prof. R. D. Kandou Manado General Hospital. The method of this study was descriptive retrospective. The highest percentage that already been obtain in the Department of Obstetric and Gynaecology in the Prof. R. D. Kandou Manado General Hospital are patients with age 45-49 with 18 cases $(20,48 \%)$, clinical stadium III B with 22 cases $(25,12 \%)$, and Patients occupation as a housewife are the highest with 61 cases $(69,35 \%)$.
\end{abstract}

Keywords: cervical cancer, age, clinical stadium, and patients occupation.

\begin{abstract}
Abstrak: Kanker serviks dan kanker payudara merupakan penyakit kanker dengan persentasi tertinggi di Indonesia pada tahun 2013, yaitu kanker serviks sebesar 0,8\% dan kanker payudara sebesar 0,5\%. Pada umumnya penyakit ini dirawat kira-kira sekitar 70-75\% sudah berada pada stadium lanjut dengan tingkat kematian yang sangat tinggi. Hingga saat ini kanker serviks merupakan penyebab kematian terbanyak akibat penyakit kanker di Negara berkembang. Penelitian ini bertujuan untuk mengetahui karakteristik penderita kanker serviks di bagian Obstetri dan Ginekologi RSUP Prof. Dr. R. D. Kandou Manado. Metode penelitian yang digunakan adalah deskriptif retrospektif. Hasil tertinggi yang didapat di bagian Obstetri dan Ginekologi RSUP Prof. R. D. Kandou Manado adalah usia 45-49 tahun dengan jumlah 18 pasien (20,48\%), stadium III B dengan jumlah 22 pasien $(25,12 \%)$, dan pekerjaan dari penderita sebagai IRT (Ibu Rumah Tangga) merupakan yang terbanyak yaitu 61 pasien $(69,35 \%)$.
\end{abstract}

Kata kunci: kanker serviks, usia, stadium klinis, dan pekerjaan penderita.

Kanker leher rahim atau kanker serviks merupakan tumor ganas primer yang berasal dari sel epitel skuamosa.

Penyakit ini berawal dari infeksi virus yang merangsang perubahan perilaku sel epitel serviks dan kemudian sel tersebut bermutasi melakukan pembelahan sel yang tidak terkendali,dan imortal, keadaan yang menyebabkan mutasi genetik yang tidak dapat diperbaiki akan menyebabkan terjadinya pertumbuhan kanker ini. ${ }^{1}$

Penyebab utama kanker serviks adalah infeksi virus HPV (Human Papilloma Virus). Lebih dari 90\% kanker serviks jenis skuamosa mengandung DNA virus HPV dan $50 \%$ kanker serviks berhubungan dengan HPV tipe $16 .{ }^{1}$

Penyebaran virus ini terutama melalui 
hubungan seksual. Hubungan seksual yang terlalu muda ( $<16$ tahun), jumlah pasangan seksual yang tinggi ( $>4$ orang) dan wanita perokok yang di ambil dari beberapa kasus penelitian ditemukan bahwa bahan karsinogenik spesifik dari tembakau dijumpai dalam lendir serviks wanita yang dapat mengakibatkan kerusakan DNA sel epitel skuamosa dan bersama dengan infeksi HPV mencetuskan transformasi maligna merupakan faktor-faktor utama terjadinya kanker serviks. ${ }^{1}$

Hingga saat ini kanker serviks merupakan penyebab kematian terbanyak akibat penyakit kanker di Negara berkembang. ${ }^{1}$

Didunia kanker serviks menempati urutan kedua terbanyak setelah keganasan payudara, dan kira-kira $10 \%$ dari seluruh penyakit keganasan pada wanita. ${ }^{2}$

Daerah Sulawesi Utara menempati urutan ke 13 dari 33 propinsi yang menderita kanker serviks. Pada tahun 2025 diperkirakan kasus baru kanker serviks di Indonesia akan meningkat sebesar $74 \%$ sementara secara keseluruhan prevalensinya akan meningkat sebersar $49 \% .^{3}$

Dari hasil penelitian secara retrospektif deskriptif terhadap karakteristik kanker serviks stadium lanjut di RSUP Prof. Dr. R. D. Kandou Manado periode 1 Januari 2010 - 31 Desember 2011 diperoleh angka kejadian kanker serviks stadium lanjut yaitu sebanyak 67 kasus. Didapatkan kelompok umur 45-49 dan 50-54 tahun adalah yang terbanyak, yaitu masingmasing 15 kasus $(22,4 \%)$, atau $44,8 \%$ dari total kasus. $^{4}$

Berdasarkan Uraian masalah di atas maka penulis ingin mengetahui lebih lanjut dan ingin menambah wawasan mengenai karakteristik penderita kanker serviks di RSUP Prof.Dr.R.D. Kandou Manado.

\section{METODE PENELITIAN}

Jenis penelitian yang dilakukan ialah deskriptif retrospektif. Penelitian ini dilakukan di Bagian Obstetri dan Ginekologi RSUP. Prof. Dr. R. D. Kandou Manado selama bulan September sampai
November 2016. Materi penelitian ini diambil dari catatan rekam medik di bagian Obstetri dan Ginekologi RSUP. Prof. Dr. R. D. Kandou Manado periode 1 Januari 2013 sampai dengan 31 Desember 2015.

Variabel yang diamati: usia, pekerjaan ibu, pekerjaan suami, pendidikan terakhir, paritas, stadium klinis, dan riwayat pap's smear.

\section{HASIL PENELITIAN DAN BAHASAN}

Berdasarkan penelitian yang telah dilakukan, didapatkan hasil sebagai berikut:

Tabel 1 memperlihatkan dari 88 kasus kanker serviks yang ditemukan dan dikelompokkan berdasarkan usia. Kelompok usia 45-49 ialah yang terbanyak, yaitu 18 kasus $(20,48 \%)$ dari 88 total kasus. Hal ini sesuai dengan kepustakaan yang mengemuka-kan bahwa kanker serviks timbul pada usia tiga puluh tahunan atau lebih. $^{7}$

Tabel 1. Distribusi kanker serviks menurut usia.

\begin{tabular}{ccc}
\hline Usia & n & \% \\
\hline$<30$ & 5 & 5,68 \\
$31-34$ & 7 & 7,95 \\
$35-39$ & 9 & 10,22 \\
$40-44$ & 13 & 14,77 \\
$45-49$ & 18 & 20,48 \\
$50-54$ & 10 & 11,36 \\
$55-59$ & 12 & 13,63 \\
$>60$ & 14 & 16 \\
Total & 88 & 100 \\
\hline
\end{tabular}

Tabel 2 didapatkan ibu atau penderita yang bekerja sebagai IRT (Ibu Rumah Tangga) adalah yang terbanyak menderita kanker serviks, yaitu 61 kasus $(69,35 \%)$ dari 88 total kasus. Pekerjaan IRT bukanlah salah satu faktor yang mengakibatkan banyaknya kejadian kanker serviks, tetapi tingkah laku sosial seperti sering gontaganti pasangan seksual dari pasangannya sangat berperan dalam melakukan penyebaran virus HPV yang mengakibatkan terjadinya penyakit kanker serviks. Walaupun pekerjaan sebagai IRT harus diteliti lagi lebih lanjut, kemungkinan besar ibu-ibu tidak menjelaskan secara lebih 
transparan bidang pekerjaannya. ${ }^{4}$

Tabel 2. Distribusi kanker serviks berdasarkan pekerjaan ibu.

\begin{tabular}{cll}
\hline Pekerjaan ibu & $\mathbf{n}$ & $\mathbf{\%}$ \\
\hline IRT & 61 & 69,35 \\
Swasta & 7 & 7,95 \\
PNS & 12 & 13,63 \\
Petani & 2 & 2,27 \\
Pensiunan & 3 & 3,40 \\
Lain-lain & 3 & 3,40 \\
Total & 88 & 100 \\
\hline
\end{tabular}

Tabel 3 berdasarkan pekerjaan suami, ternyata suami yang bekerja sebagai PNS (Pegawai Negeri Sipil) merupakan yang terbanyak yaitu 9 kasus $(10,30 \%)$ dari 88 total kasus. Pekerjaan suami merupakan faktor yang sangat berpengaruh terhadap penyebaran atau kejadian kanker serviks, dikarenakan karakteristik dari virus yang bersangkutan yang disebut HPV (Human Papilloma Virus).

Tabel 3. Distribusi kanker serviks berdasarkan pekerjaan suami.

\begin{tabular}{llc}
\hline Pekerjaan Suami & n & \% \\
\hline Petani & 8 & 9,1 \\
Swasta & 7 & 7,95 \\
PNS & 9 & 10,30 \\
Pensiunan & 3 & 3,40 \\
Nelayan & 1 & 1,15 \\
Buruh & 4 & 4,54 \\
Tukang & 2 & 2,2 \\
Meninggal & 5 & 5,68 \\
Tidak ada data & 49 & 55,68 \\
Total & 88 & 100 \\
\hline
\end{tabular}

Tabel 4 pasien yang berpendidikan terakhir tamat SMA merupakan yang terbanyak menderita kanker serviks yaitu 50 kasus $(56,83 \%)$ dari total 88 kasus. Memiliki pendidikan atau pengetahuan yang tinggi dapat menunjang tingkat kesehatan dan kehidupan masing-masing individu, dengan pemikiran yang luas dan kesadaran terhadap bahaya nya penyakit kanker serviks kita dapat melakukan deteksi dini untuk mencegah terjadinya penyakit tersebut.
Tabel 4. Distribusi kanker serviks berdasarkan pendidikan terakhir.

\begin{tabular}{lcc}
\hline $\begin{array}{l}\text { Pendidikan } \\
\text { terakhir }\end{array}$ & n & $\boldsymbol{\%}$ \\
\hline Tamat SD & 18 & 20,45 \\
Tamat SMP & 11 & 12,5 \\
Tamat SMA & 50 & 56,83 \\
Perguruan Tinggi & 7 & 7,95 \\
Tidak ada data & 2 & 2,27 \\
Total & 88 & 100 \\
\hline
\end{tabular}

Tabel 5 dari 88 kasus, ditemukan 52 pasien $(59 \%)$ dengan jumlah paritas $\geq \mathrm{P}_{3}$ adalah yang terbanyak. Hasil yang ditemukan ini tidak berbeda dengan kepustakaan dimana menyatakan bahwa makin tinggi paritas maka insidensi kanker serviks makin tinggi, tingginya paritas bukan merupakan penyebab tetapi sebagai salah satu faktor risiko untuk terinfeksi HPV risiko tinggi. ${ }^{4-6}$

Tabel 5. Distribusi kanker serviks berdasarkan paritas.

\begin{tabular}{lll}
\hline Paritas & $\mathbf{n}$ & \% \\
\hline $\mathrm{P}_{0}$ & 3 & 3 \\
$\mathrm{P}_{1}$ & 14 & 16 \\
$\mathrm{P}_{2}$ & 19 & 22 \\
$\geq \mathrm{P}_{3}$ & 52 & 59 \\
Total & 88 & 100 \\
\hline
\end{tabular}

Tabel 6 menunjukan bahwa banyak pasien datang berobat sudah dalam keadaan stadium lanjut, dikarenakan kejadian tertinggi berada pada stadium klinis III $_{B}$ dengan angka kejadian 22 kasus $(25,15 \%)$. Hal ini dikarenakan kanker serviks pada stadium awal belum menimbulkan keluhan atau gejala klinis spesifik seperti sekret yang berlebihan, sehingga banyak pasien datang pada stadium lanjut dikarenakan beberapa keluhan sudah mulai timbul seperti nyeri pinggang, sering berkemih, terdapat perdarahan spontan, dan keluar cairan pervaginam yang berbau busuk. ${ }^{8}$ Juga sangat disayangkan minimnya pengetahuan dan edukasi bagi penderita sehingga terlambat melakukan pemeriksaan. 
Tabel 6. Distribusi kanker serviks berdasarkan stadium klinis.

\begin{tabular}{lll}
\hline Stadium & n & \% \\
\hline $\mathrm{I}_{\mathrm{A}}$ & 2 & 2,27 \\
$\mathrm{I}_{\mathrm{B}}$ & 5 & 5,68 \\
$\mathrm{I}_{\mathrm{B} 2}$ & 3 & 3,40 \\
$\mathrm{II}_{\mathrm{A}}$ & 15 & 17 \\
$\mathrm{II}_{\mathrm{A} 2}$ & 5 & 5,68 \\
$\mathrm{II}_{\mathrm{B}}$ & 16 & 18,18 \\
$\mathrm{III}_{\mathrm{A}}$ & 15 & 17 \\
$\mathrm{III}_{\mathrm{B}}$ & 22 & 25,12 \\
$\mathrm{IV}$ & 1 & 1,13 \\
$\mathrm{IV}$ & 2 & 2,27 \\
Tidak ada data & 2 & 2,27 \\
Total & 88 & 100 \\
\hline
\end{tabular}

Tabel 7 memperlihatkan bahwa penderita kanker serviks yang pernah melakukan skrining pap's smear terdapat 3 kasus $(3,40 \%)$ sedangkan 85 kasus $(96,60)$ tidak pernah melakukan skrining pap's smear. Banyak upaya yang telah dilakukan dari pemerintah sampai tenaga kesehatan untuk mencegah terjadinya penyakit kanker serviks dengan melakukan sosialisasi sampai melakukan pemeriksaan gratis dengan metode pap's smear dan IVA "Inspeksi Visual Asam Asetat", tetapi masih banyak juga masyarakat yang kurang edukasi dan kurang kesadaran terhadap bahayanya penyakit kanker serviks.

Tabel 7. Distribusi kanker serviks menurut riwayat Pap's smear.

\begin{tabular}{llc}
\hline Pap's Smear & n & \% \\
\hline Ada & 3 & 3,40 \\
Tidak ada data & 85 & 96,60 \\
$\quad$ Total & 88 & 100 \\
\hline
\end{tabular}

\section{SIMPULAN}

Dari hasil penelitian mengenai karakteristik penderita kanker serviks di RSUP Prof. Dr. R. D. Kandou Manado periode 1 Januari 2013 - 31 Desember 2015 didapatkan angka kejadian kanker serviks yaitu 88 kasus. Kelompok umur 4549 adalah yang terbanyak yaitu 18 kasus $(20,48 \%)$. Penderita kanker serviks memiliki pendidikan terakhir SMA yaitu 50 kasus $(56,83 \%)$, pekerjaan sebagai IRT sebanyak 61 kasus $(69,35 \%)$, dan pekerjaan suami sebagai PNS yang terbanyak yaitu 9 kasus $(10,30 \%)$ dari 88 total kasus. Jumlah paritas lebih dari $3 \quad\left(\geq \mathrm{P}_{3}\right)$ adalah yang terbanyak menderita kanker serviks dengan jumlah $52(59 \%)$ dan stadium $\mathrm{III}_{\mathrm{B}}$ yang terbanyak didapati yaitu $22(25,12 \%)$ dari 88 total kasus. Pemeriksaan pap's smear masih kurang dari 88 total kasus hanya 3 orang yang pernah melakukan pemeriksaan pap's smear $(3,40 \%)$.

\section{SARAN}

1. Perlu dilakukan sosialisasi lebih luas terhadap bahayanya kanker serviks agar menambah kesadaran masyarakat terhadap penyakit tersebut.

2. Disarankan pula wanita yang sudah masa reproduksi perlu melakukan skrining Pap's Smear ataupun IVA untuk mendeteksi lebih dini kemungkinan terkena penyakit kanker serviks.

3. Disarankan pihak administrasi khususnya dalam catatan rekam medik dilengkapi, karena saat penelitian sangat disayangkan banyak data yang tidak lengkap.

DAFTAR PUSTAKA

1. Sarwono P. Kanker Serviks. In: M. Farid Azis, Andri Jono, Abdul Bari Saifuddin, editors. Buku Acuan Nasional Onkologi Ginekologi. Edisi Pertama. Jakarta: Yayasan Bina Pustaka Sarwono Prawirohardjo; 2006.p. 44254.

2. Gershenson DM, Mcguire WP, Gore M, Quinn MA, Thomas G. Gynecologic Cancer: Controversies in Management. New York: Elsevier Churchill Livingstone, 2004; p.4-22.

3. WHO/ICO. Information centre on HPV and cervical cancer.Human papilloma virus and related cancers in world. Summary report update $2010 \mathrm{Lc} 2010$.

4. Rarung R, Loho M, Suparman E. Karakteristik penderita kanker serviks Stadium Lanjut di RSUP PROF. DR. R. D. KANDOU. Manado: Fakultas Kedokteran UNSRAT. Jurnal eBiomedik (eBM), 2013;1:566-70 
5. Rasjidi I. Deteksi Dini \& Pencegahan Kanker pada Wanita. Jakarta: Sagung Seto, 2009, p.97-143.

6. Ketut IS. Tes Human Papillomavirus sebagai Skrining Alternatif Kanker Serviks. Cermin Dunia Kedokteran. 2006; 151: 29-30.

7. Sarwono P, Wiknjosastro H, Sumapraja S, Saifuddin A. Kanker Ganas Alat Genital. Anwar M, Baziad A, Prabowo
R. Ilmu Kandungan Edisi Ketiga. Jakarta: Yayasan Bina Pustaka Sarwono Prawirohardjo; 2014.p. 29498.

8. "Human Papilloma virus (HPV) Vaccines Q \& A". Fact Sheets: Risk Factors and Possible Causes. National Cancer Institute (NCI). 2009-10-22. Retrieved 2009-11-11. 